\title{
TRANSFUSION-TRANSMITTED MALARIA: CASE REPORT OF ASYMPTOMATIC DONOR HARBORING Plasmodium malariae
}

Patricia SCURACCHIO(1), Sergio Domingos VIEIRA(1), Denise Albuquerque DOURADO(1), Luciana Moro BUENO(1), Rafael COLELLA(1), Eduardo Milton RAMOS-SANCHEZ(2), Giselle F. M. Castro LIMA(3), Juliana INOUE(3), Maria Carmen Arroyo SANCHEZ(2) \& Silvia Maria DI SANTI(3)

\begin{abstract}
SUMMARY
Malaria in Brazil is endemic in the Amazon region, but autochthonous cases with low parasitaemia occur in the Atlantic Forest area of the country. According to Brazilian legislation no test is mandatory for blood donors from non-endemic areas. However if they have traveled to malaria transmission regions they are deferred for six months before they can donate. This report describes a transfusion-transmitted malaria case in Sao Paulo, Brazil, where one recipient received infected blood and developed the disease. He lived in Sao Paulo and had no previous transfusion or trips to endemic areas, including those of low endemicity, such as Atlantic Forest. Thick blood smears confirmed Plasmodium malariae. All donors lived in Sao Paulo and one of them (Donor 045-0) showed positive hemoscopy and PCR. This asymptomatic donor had traveled to Juquia, in the Atlantic Forest area of Sao Paulo State, where sporadic cases of autochthonous malaria are described. DNA assay revealed P. malariae in the donor's (Donor 045-0) blood. Serum archives of the recipient and of all blood donors were analyzed by ELISA using both $P$. vivax and $P$. falciparum antigens, and IFAT with $P$. malariae. Donor 045-0's serum was $P$. malariae IFAT positive and the $P$. vivax ELISA was reactive. In addition, two out of 44 donors' archive sera were also $P$. vivax ELISA reactive. All sera were $P$. falciparum ELISA negative. This case suggests the need of reviewing donor selection criteria and deferral strategies to prevent possible cases of transfusion-transmitted malaria.
\end{abstract}

KEYWORDS: Transfusion-transmitted malaria; PCR; Malaria serology; Malarial DNA; Atlantic Forest.

\section{INTRODUCTION}

Malaria occurs in more than 100 countries in the tropical and subtropical regions including parts of Asia, Africa, Oceania, Central and South America. Half of the world's population is at risk of malaria and an estimated 243 million cases led to nearly 863,000 deaths in 2008, mostly in children living in sub-Saharan Africa ${ }^{34}$. In Brazil, 306,908 cases were notified in 2009, being 306,342 in the Amazon region, where malaria is endemic ${ }^{5}$. P. vivax is the most common species $(84.4 \%)$, followed by $P$. falciparum (14.6\%), mixed infections $(0.9 \%)$ and $P$. malariae $(0.02 \%)^{3}$, however it is important to note that $P$. malariae may be misdiagnosed due to the difficulty of differentiating it from $P$. vivax. Outside of the Amazon region the National Malaria Control Program notified 154 autochthonous cases in $2008^{4}$.

Data about the frequency of transfusion transmitted malaria show values that vary from less than 0.2 in non-endemic countries to 50 or more cases per million in endemic countries ${ }^{6}$ and the species most frequently associated with transfusional cases are $P$. falciparum, $P$. malariae and $P$. vivax. The donors implicated in this kind of transmission are invariably semi-immune, with parasite levels below the detection threshold of currently available assays. As the result of the asymptomatic persistence of parasites, transmission has been documented after the last exposure as long as 44 years for $P$. malariae, five years for $P$. vivax and eight years for $P$. falciparum ${ }^{23,27}$. Besides that, parasites can survive in blood at temperatures between $2{ }^{\circ} \mathrm{C}$ and $6{ }^{\circ} \mathrm{C}$ for until three weeks, with the estimated inoculum in transfusions from one to 10 parasites per donation ${ }^{7,20,31}$. Whole blood and red blood cell units are the primary carriers of malaria transmitted by transfusion, although platelets and leukocytes may contain variable numbers of red cells and have, rarely, transmitted malaria ${ }^{12,18,35}$.

In endemic regions transfusion transmitted malaria has frequently been described. In a recent prospective study in Pakistan, healthy volunteer blood donors were screened by thick blood smear and showed $0.57 \%$ positivity, with one case of $P$. falciparum and eight due to $P$. vivax $^{1}$. In a study conducted in India 11,736 units of blood were screened from 2008 to 2009 , with $0.03 \%$ positivity using rapid diagnostic tests that was confirmed by microscopy ${ }^{2}$. In Nigeria, where blood donors are not routinely tested for malarial infection, potential blood donors were screened, resulting in a positivity of $20.2 \%$ by microscopy, $3.8 \%$ by OptiMAL and $57.8 \%$ by Clinotech ${ }^{16}$. 


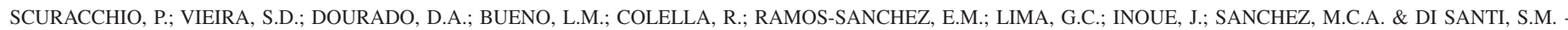
Transfusion-transmitted malaria: case report of asymptomatic donor harboring Plasmodium malariae. Rev. Inst. Med. Trop. Sao Paulo, 53(1): 55-9, 2011.

The risk of transfusion-transmitted malaria differs widely among low endemic countries, where the imported infection occurs in individuals that have traveled to or migrated from endemic regions ${ }^{24}$. In a survey conducted in 14 national transfusion services centers in different countries, the use of serological tests for malaria in donor screening was reported as a routine only in four countries (United Kingdom, Denmark, Finland and New Zealand). Those with positive serology are confirmed by rapid tests for detection of antigens in New Zealand and nucleic acid testing (NAT) in the United Kingdom where no case of transfusiontransmitted malaria was diagnosed during the last 5 years ${ }^{28}$.

According to Brazilian guidelines there are different recommendations for endemic and non-endemic regions. The endemic area is classified into low, medium or high risk, based on the Annual Parasite Index. In endemic areas those donors who have had malaria in the 12 months preceding the donation and those coming from areas of high malaria risk are rejected, as well as those donors that presented fever or are suspected of having malaria in the last 30 days. Donors from areas of medium and low risk can be accepted after a negative thick film or rapid malaria test. In non-endemic areas testing is not required nor performed, but donors who were in an endemic area with active transmission in the last six months and those that have had malaria or resided in endemic areas in the last three years are excluded. In both endemic and non-endemic areas donors who have had infection with $P$. malariae are excluded ${ }^{29}$. Some transfusion services use antibody assays such as Indirect Fluorescent Antibody Test (IFAT) and enzyme-linked immunosorbent assay (ELISA) in addition to antigenic tests. Molecular tests are used only for diagnosis or research in reference centers. Even in non-endemic areas and with all the precautionary measures being taken, exclusion of all 'malaria risk' individuals is not possible.

A further limitation to travel-based restrictions is that the long periods of asymptomatic carriage, particularly associated with $P$. malariae, also mean that donors can harbor parasites even after their exclusion period. Besides that, current strategies to reduce the likelihood of transfusion transmitted infections in non-endemic countries invariably involve discarding blood from potentially exposed donors, possibly leading to wastage of donations.

In the last 10 years cases of transfusion-transmitted malaria have been reported in a number of countries: two in France ${ }^{19}$; two in Italy, three in Brazil ${ }^{10,21}$ and one in $\mathrm{USA}^{28}$, one in Republic of Korea ${ }^{25}$; one in United Kingdom ${ }^{22}$.

\section{CASE REPORT}

We describe a case of transfusion-transmitted malaria due to $P$. malariae from an asymptomatic donor attended in a private blood bank in the city of Sao Paulo. On August $12^{\text {th }} 2008$, a patient was admitted for cardiac surgery and received five units of red blood cells, 10 of cryoprecipitate, 20 of platelets and 15 of fresh frozen plasma from 50 different donors. This patient had always lived in Sao Paulo city and denied any previous transfusion before this surgery or of having traveled to malaria endemic areas, including low-endemicity ones, such as Atlantic Forest. The patient had negative serological tests for malaria before transfusion (Table 1). On October $27^{\text {th }} 2008$ he developed fever, chills, arthralgia and sweating. Laboratory tests were carried out and the thick films from peripheral blood showed the presence of $P$. malariae. As this recipient received five units of red blood cells, the respective donors were recalled for epidemiological investigation and to perform thick films, PCR and serology. Four out of five donors attended the recall, all of them living in Sao Paulo. Only one donor (045-0) presented positive tests (Table 1, Fig. 1, Fig. 2). Since 1983 this donor traveled on a number of occasions to Juquia City, located in the Atlantic Forest area of Sao Paulo State, and where sporadic cases of autochthonous malaria are described. His last visit was in December 2007. Previously, he had last donated blood in 1990. On examination his thick film showed scarce parasites without clear species determination (Fig. 1A). Nested PCR based on the detection of species-specific sequences of small-subunit rRNA genes of Plasmodium ${ }^{32}$ was done, and revealed the presence of $P$. malariae in the donor's blood (Fig. 1B). Sera archives of the recipient and of 48 blood donors were recovered and analyzed for the presence of malarial antibodies using an IgG IFAT with $P$. malariae antigen, an ELISA $^{8}$ with $P$. vivax recombinant antigen $\left(\mathrm{r} P v \mathrm{MSP} 1_{19}\right)$ and an ELISA using total extract of $P$. falciparum asexual forms. The $P$. malariae IFAT $^{17}$ was positive only in donor 045-0 (Fig. 1C). The P. vivax ELISA was reactive with the sera from the infected donor (045-0) and two of the other 48 donors' archive sera (Fig. 2). All archive sera were negative in the $P$. falciparum ELISA. Both the blood donor and the recipient were treated successfully.

\section{DISCUSSION}

In Sao Paulo State, from 1980 to 2007, 821 autochthonous cases of malaria were reported; $91.6 \%$ occurred in the eastern region and these were predominantly due to $P$. vivax, as determined by microscopy; $9.6 \%$ of cases were asymptomatic ${ }^{9}$. It is important to note that the diagnosis of $P$.

Table 1

Molecular, parasitological and serological test results from receptor before and after transfusion, and from the infected donor related to transfusional malaria

\begin{tabular}{|c|c|c|c|}
\hline \multirow[t]{2}{*}{ Tests } & \multicolumn{2}{|c|}{ Receptor } & \multirow[t]{2}{*}{ Infected donor } \\
\hline & Before transfusion & After transfusion & \\
\hline PCR & ND & ND & P. malariae \\
\hline TBS & ND & P. malariae & Plasmodium $\mathrm{sp}$ \\
\hline IFAT- $P m$ & Negative & ND & Positive \\
\hline ELISA $P f$ & Negative & ND & Negative \\
\hline ELISA $P v$-MSP $1_{19}$ & Negative & ND & Positive \\
\hline
\end{tabular}

PCR - polymerase chain reaction; TBS - thick blood smear; IFAT - indirect fluorescent assay test; ELISA - Enzyme-linked immunosorbent assay; ND - not done. 

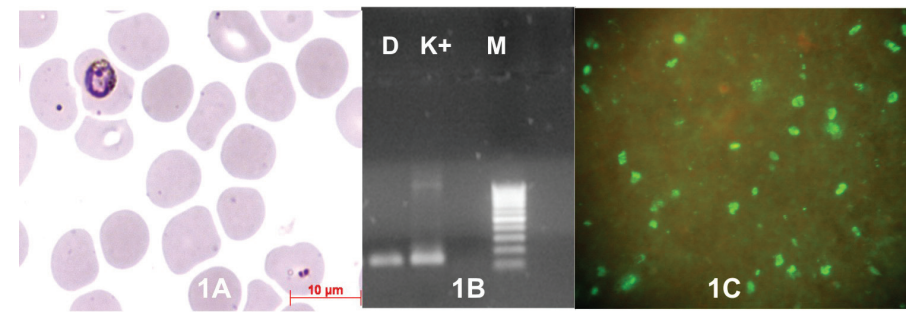

Fig. 1 - 1A - Plasmodium with atypical morphology in thin blood smear from asymptomatic donor living in low transmission area. 1B - Nested PCR based on the detection of speciesspecific sequences of small-subunit rRNA genes, showing Plasmodium malariae bands (144 bp) of donor sample (D), positive control (K+) and 100 bp marker (M). 1C - IFAT of infected donor serum with $P$. malariae antigen.

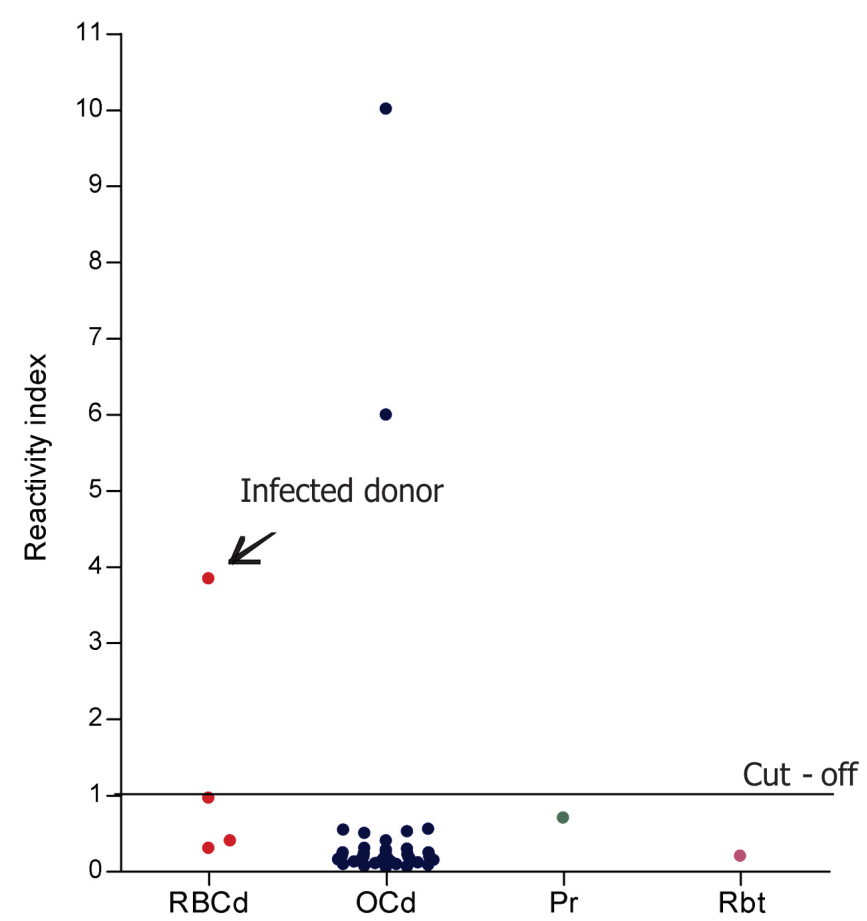

Fig. 2 - Reactivity index of four red blood cells donors (red dots), 44 other blood components donors (blue dots), 1 platelet recipient from the infected donor (green dot) and the Plasmodium malariae infected recipient, before transfusion (purple dot), using ELISA with $\mathrm{r} P v \mathrm{MSP} 1_{19}$.

vivax by thick film was not confirmed by PCR because this methodology is only available in the reference center. Due to the usually low level parasitaemia encountered in these clinical cases it is extremely difficult to differentiate $P$. vivax from $P$. malariae.

Symptomless infections with low parasitemia, confirmed by molecular tools as P. malariae, can occur in the Atlantic Forest area. Transfusion-transmitted malaria is a possibility associated with donors who either live in or have traveled to this area, reinforcing the need to monitor these donations. Three recent cases related to $P$. malariae, two of them in splenectomized receptors, including one lethal, originated from infectious donations from asymptomatic donors ${ }^{10,21}$. Tests carried out to detect the donors involved in the transmission showed high titers against $P$. malariae in IFAT and positive PCR. They had no report of traveling to Amazon region, although had visited the Atlantic Forest area in the State of Sao Paulo, where sporadic autochthonous cases have persistently been reported. Similar cases may have occurred without being identified.

According to Brazilian legislation ${ }^{29}$ no malaria tests are mandatory in blood donors living in non-endemic areas, but they are deferred for donation for six months if they have traveled to endemic or autochthonous malaria transmission regions.

This report is relevant because the transmission occurred despite a careful interview with the blood donors when they were asked about previous residence in and travel to endemic areas. This measure was not able to prevent transfusion transmission of malaria, since the donor had traveled to an area with very low transmission rates and where symptomless malaria cases occur, mainly due to $P$. malariae. The limited knowledge about the epidemiology of the disease in the low transmission regions by health professionals also contributes to failure in donor screening. In this case, the donor remained asymptomatic and had traveled to a low transmission area eight months before blood donation, indicating that the six months period of deferral on its own is not sufficient in such situations. Furthermore, increasing the deferral period to exclude candidates whose displacement occurred more than six months before the donation could affect blood supply drastically. The use of nested PCR in this case allowed the diagnosis of very low parasitemia in the blood donor, since this method can detect one parasite per microlitre ${ }^{32}$. This result was corroborated with the homologous antigen $P$. malariae in IFAT. This serological technique as well as ELISA is commonly used to detect malarial antibodies. DODERER et al. ${ }^{11}$ compared two serological assays and obtained clinical sensitivity of $84.2 \%$ and specificity of $99.6 \%$ by DiaMed ELISA and $70.5 \%$ and $99.6 \%$ respectively, using the IFAT method. SEED et al. ${ }^{31}$ used an enzyme-linked immunoassay (Newmarket) and the results pointed out to the usefulness of a screening strategy combining antibody testing with a 6-month cellular component restriction period for donors with a declared malarial risk. Recently the restriction period was shortened to 4-month combined with a sensitive antibody screening test for donors with malarial risk and the risk of transfusional malaria in Australia remains low $^{30}$. In France, a multicentre study was performed in nine blood banks to compare IFAT and DiaMed ELISA, obtaining a rate of concordance of $92.6 \%$ in retrospective samples and $97 \%$ in the prospective group, corroborating with the potential use of ELISA test in blood bank screening, as an alternative to the IFAT in non-endemic areas ${ }^{14}$. Since all human Plasmodia have been implicated in transfusional malaria, a new assay based on detection of antibodies anti $\mathrm{MSP}_{19}$ of $P$. falciparum, P. malariae, $P$. ovale and P. vivax is now available ${ }^{26}$.

Non-endemic countries have discussed measures in order to prevent transfusional malaria. In France, a successful strategy has been in use since 1986, based on self-exclusion, questionnaire, medical interview and serological screening prior to blood donation. Individuals who have had malaria in the past are permanently deferred. These measures lead to the reduction of five- to 10 -fold in the number of cases. Three transfusional accidents notified from 1999 to 2006 were due to failure on data obtained by the questionnaires and lack of prescription of serology. According to French and British hemovigilance networks, no transfusional malaria in both countries was a consequence of missed serological positivity. Blood transfusion services, in a number of other non-endemic countries, are also 
SCURACCHIO, P.; VIEIRA, S.D.; DOURADO, D.A.; BUENO, L.M.; COLELLA, R.; RAMOS-SANCHEZ, E.M.; LIMA, G.C.; INOUE, J.; SANCHEZ, M.C.A. \& DI SANTI, S.M. Transfusion-transmitted malaria: case report of asymptomatic donor harboring Plasmodium malariae. Rev. Inst. Med. Trop. Sao Paulo, 53(1): 55-9, 2011.

currently considering the adoption of serology. Therefore, an adequate strategy for minimizing the risk of malaria transmitted by blood in nonendemic areas without losing donations is a combination of suitable donor selection and deferral together with screening for malarial antibodies ${ }^{19}$.

In our case, it is important to review the criteria adopted in the clinicalepidemiological trials recommended by Brazilian guidelines, in order to ensure that the appropriate and effective donor selection guidelines are developed to implement suitable screening strategies to ensure blood safety. This review must consider including additional and relevant questions such as: place of birth, previous malaria history, residence during donor's lifetime and travel history, even if they have traveled only to areas of low endemicity. Recent and accurate data on malaria prevalence and incidence must be available for Transfusion Centers to avoid failure in the identification of low transmission areas where symptomless cases can occur. In the Atlantic Forest of Sao Paulo State P. malariae was first reported based on molecular diagnosis after the investigation of a case of transfusion-transmitted malaria $^{21}$. This species of Plasmodium is genetically indistinguishable of $P$. brasilianum with respect to the CSP gene ${ }^{15}$ and also to two other nuclear genes, SSUrRNA and the protein-encoding MSP-1 ${ }^{33}$. DUARTE et al. ${ }^{13}$ tested by PCR blood samples from Alouatta guariba clamitans from the Sao Paulo Atlantic Forest and detected $5.6 \%$ of P. malariae and $5.6 \%$ of $P$. vivax. Since there are many summer holiday residences near the forest it is thought that malaria probably occurs as a zoonosis in this area.

The introduction of a serological test for malaria, together with good donor selection guidelines, could lead to the deferral of those donors most likely to have asymptomatic infections and thus reduce the risk of transfusion-transmitted malaria in Brazil

\section{RESUMO}

\section{Malária transfusional: relato de caso de doador assintomático infectado por Plasmodium malariae}

No Brasil a malária é endêmica na Amazônia, porém casos autóctones com baixas parasitemias ocorrem na área costeira de Mata Atlântica. De acordo com a legislação brasileira, não são obrigatórios testes para detecção de malária em doadores de sangue de áreas nãoendêmicas; entretanto são excluídos por seis meses aqueles com relato de deslocamento para áreas de transmissão. Este trabalho descreve um caso de malária transfusional ocorrido em São Paulo, Brasil, em que um paciente recebeu sangue infectado, desenvolvendo a doença. Ele residia em São Paulo e não apresentava histórico de transfusão anterior ou deslocamentos para áreas endêmicas, incluindo as de baixa endemicidade, como a Mata Atlântica. A gota espessa revelou Plasmodium malariae. Os doadores eram residentes em São Paulo e um deles (045-0) apresentou hemoscopia e PCR positivos. Este era assintomático com PCR positiva para P. malariae e viagem para Juquiá, Mata Atlântica de São Paulo, onde são descritos casos esporádicos de malária autóctone. Amostras de soro do receptor e de todos os doadores foram ensaiadas por ELISA com antígenos de $P$. vivax e $P$. falciparum e RIFI com $P$. malariae. O doador 045-0 apresentou RIFI positiva para $P$. malariae. ELISA- $P$. vivax foi reagente no doador infectado (045-0) e em dois dos 44 doadores. Todos os soros foram negativos com antígeno de P. falciparum. Este caso aponta a necessidade de revisão dos critérios de triagem clínicoepidemiológica para evitar casos transfusionais e também adequar as estratégias de exclusão de doadores de sangue.

\section{ACKNOWLEDGEMENTS}

This work was supported by: 1) Health Secretariat of Sao Paulo State and Tropical Medicine Institute of Sao Paulo, as part of a technical cooperation agreement; 2) "Banco de Sangue de São Paulo", São Paulo, SP, Brazil.

\section{REFERENCES}

1. Ali N, Ahmed J, Ali N, Jehan F, Saleem S. Transfusion transmitted malaria in three major blood banks of Peshawar, Pakistan. Afr J Biotechnol. 2010;9:5445-9.

2. Bahadur S, Pujani M, Jain M. Use of rapid detection tests to prevent transfusiontransmitted malaria in India. Asian J Transfus Sci. 2010;4:140-1.

3. Brasil. Ministério da Saúde. Secretaria de Vigilância em Saúde. DATASUS. Sistema de Informação de Vigilância Epidemiológica - SIVEP - Malária. 2009. [cited 2010 Oct 19]. Available from: http://dw.saude.gov.br/portal/page/portal/sivep_malaria/ TAB99449:tab_resumo_n?Ano_n=2009.

4. Brasil. Ministério da Saúde. Secretaria de Vigilância em Saúde. Sistema de Informação de Agravos de Notificação. Brasília: SINAN; 2010.

5. Brasil. Ministério da Saúde. Sistema de Informação de Vigilância Epidemiológica - Malaria (Sivep-Malária). 2010. [Cited 2010 Oct 19]. Available from: http://portal.saude.gov. br/portal/arquivos/pdf/tab_casos_confirmados_malaria_bra_gr_e_ufs_90a09.pdf.

6. Bruce-Chwatt LJ. Transfusion associated parasitic infections. Prog Clin Biol Res. 1985;182:101-25.

7. Chattopadhyay R, Majam VF, Kumar S. Survival of Plasmodium falciparum in human blood during refrigeration. Transfusion. 2010 Sep 16. doi: 10.1111/j.15372995.2010.02872.x.

8. Coelho JS, Soares IS, Lemos EA, Jimenez MCS, Kudó ME, Moraes SL, et al. A multianalyte Dot-ELISA for simultaneous detection of malaria, Chagas disease, and syphilis-specific IgG antibodies. Diagn Microbiol Infect Dis. 2007;58:223-30.

9. Couto RD, Latorre MR, Di Santi SM, Natal D. Malária autóctone notificada no Estado de São Paulo: aspectos clínicos e epidemiológicos de 1980 a 2007. Rev Soc Bras Med Trop. 2010;43:52-8.

10. Di Santi SM, Carvalho ME, Costa MJ, Kirchgatter K, Pereira BF, Toniolo C, et al. Malária transfusional causada por Plasmodium malariae transmitido por doador assintomático infectado na Mata Atlântica do Estado de São Paulo. In: XL Congresso da Sociedade Brasileira de Medicina Tropical e I Encontro de Medicina Tropical do Cone Sul, 2005; Florianópolis; Sociedade Brasileira de Medicina Tropical; 2005 Mar 6-10. Abstract PR75. (Rev Soc Bras Med Trop. 2005;38(Suppl 1):333.

11. Doderer C, Heschung A, Guntz P, Cazenave JP, Hansmann Y, Senegas A, et al. A new ELISA kit which uses a combination of Plasmodium falciparum extract and recombinant Plasmodium vivax antigens as an alternative to IFAT for detection of malaria antibodies. Malar J. 2007;6:19.

12. Dover AS, Guinee VF. Malaria transmission by leucocyte component therapy. JAMA. 1971;217:1701-2.

13. Duarte AM, Malafronte R dos S, Cerutti C Jr, Curado I, de Paiva BR, Maeda AY, et al. Natural Plasmodium infections in Brazilian wild monkeys: reservoirs for human infections? Acta Trop. 2008;107:179-85.

14. Elghouzzi MH, Senegas A, Steinmetz T, Guntz P, Barlet V, Assal A, et al. Multicentric evaluation of the DiaMed enzyme-linked immunosorbent assay malaria antibody test for screening of blood donors for malaria. Vox Sang. 2008;94:33-40.

15. Escalante AA, Barrio E, Ayala FJ. Evolutionary origin of human and primate malarias: evidence from the circumsporozoite protein gene. Mol Biol Evol. 1995;12:616-26. 
SCURACCHIO, P.; VIEIRA, S.D.; DOURADO, D.A.; BUENO, L.M.; COLELLA, R.; RAMOS-SANCHEZ, E.M.; LIMA, G.C.; INOUE, J.; SANCHEZ, M.C.A. \& DI SANTI, S.M. Transfusion-transmitted malaria: case report of asymptomatic donor harboring Plasmodium malariae. Rev. Inst. Med. Trop. Sao Paulo, 53(1): 55-9, 2011.

16. Falade CO, Nash O, Akingbola TS, Michael OS, Olojede F, Ademowo OG. Blood banking in a malaria-endemic area: evaluating the problem posed by malarial parasitaemias. Ann Trop Med Parasitol. 2009;103:383-92.

17. Ferreira AW, Sanchez MCA. Malária humana: padronização e otimização de testes sorológicos para diagnóstico individual e inquéritos epidemiológicos. Rev Inst Med Trop Sao Paulo. 1988;30:137-46.

18. Garfield MD, Ershler WB, Maki DG. Malaria transmission by platelet concentrate transfusion. JAMA. 1978;240:2285-6.

19. Garraud O, Assal A, Pelletier B, Danic B, Kerleguer A, David B, et al. Overview of revised measures to prevent malaria transmission by blood transfusion in France. Vox Sang. 2008;95:226-31.

20. Grant DB, Perinpanayagam MS, Shute PG, Zeitlin RA. A case of malignant tertian (Plasmodium falciparum) malaria after blood-transfusion. Lancet. 1960;2:469-70.

21. Kirchgatter K, Nogueira SL, Padilha A, Curado I, Boulos M, Di Santi SM. Lethal malaria caused by Plasmodium malariae in an asplenic patient in Brazil. BMJ. 2005;331(7516):576b. (Available from: http://bmj.bmjjournals.com/cgi/ eletters/331/7516/576b

22. Kitchen A, Mijovic A, Hewitt P. Transfusional transmitted malaria: current donor selection guidelines are not sufficient. Vox Sang. 2005;88:200-1.

23. Kitchen AD, Barbara JAJ, Hewit PE. Documented cases of post-transfusion malaria occurring in England: a review in relation to current and proposed donor-selection guidelines. Vox Sang. 2005;89:77-80.

24. Kitchen AD, Chiodini PL. Malaria and blood transfusion. Vox Sang. 2006;90:77-84.

25. Lee YH, Lee HK, Choi KH, Hah JO, Lim SY. Transfusion-induced malaria in a child after open heart surgery in Korea. J Korean Med Sci. 2001;16:789-91.

26. Muerhoff AS, Birkenmeyer LG, Coffey R, Dille BJ, Barnwell JW, Collins WE, et al. Detection of Plasmodium falciparum, $P$. vivax, $P$. ovale, and $P$. malariae merozoite surface protein 1-p19 antibodies in human malaria patients and experimentally infected nonhuman primates. Clin Vaccine Immunol. 2010;17:1631-8.
27. Mungai M, Tegtmeier G, Chamberland M, Parise M. Transfusion-transmitted malaria in the United States from 1963 through 1999. N Engl J Med. 2001;344:1973-8.

28. Reesink HW, Panzer S, Wendel S, Levi JE, Ullum H, Ekblom-Kullberg S, et al. The use of malaria antibody tests in the prevention of transfusion-transmitted malaria. Vox Sang. 2010;98:468-78.

29. Resolução RDC n ${ }^{\circ} 153$, de 14 de junho de 2004, ANVISA - Agência Nacional de Vigilância Sanitária. D.O.U. - Diário Oficial da União; Poder Executivo, de 24 de junho de 2004, Brasil. (Cited 2010 Oct 19]. Available from: http://www.anvisa.gov.br/sangue/legis/ sangue_componentes.htm\#resolucoes.

30. Seed CR, Kee G, Wong T, Law M, Ismay S. Assessing the safety and efficacy of a testbased, targeted donor screening strategy to minimize transfusion transmitted malaria. Vox Sang. 2010;98:182-92.

31. Seed CR, Kitchen A, Davis TM. The current status and potential role of laboratory testing to prevent transfusion-transmitted malaria. Transfus Med Rev. 2005;19:229-40.

32. Snounou G, Viriyakosol S, Zhu XP, Jarra W, Pinheiro L, do Rosario VE, et al. High sensitivity of detection of human malaria parasites by the use of nested polymerase chain reaction. Mol Biochem Parasitol. 1993;61:315-20.

33. Tazi L, Ayala FJ. Unresolved direction of host transfer of Plasmodium vivax v. P. simium and P. malariae v. P. brasilianum. Infect Genet Evol. 2011;11:209-21.

34. World Health Organization. World Malaria Report 2009. Geneva: WHO; 2009.

35. Wylie BR. Transfusion transmitted infection: viral and exotic diseases. Anaesth Intensive Care. 1993;31:24-30.

Received: 20 August 2010

Accepted: 6 December 2010 